\title{
HBZ Gene
}

National Cancer Institute

\section{Source}

National Cancer Institute. HBZ Gene. NCI Thesaurus. Code C84965.

This gene plays a role in the transport of oxygen to tissues of the fetus. 